\section{Growth Enhancement of Container- grown Pawpaw Seedlings as Influenced by Media Type, Root-zone Temperature, and Fertilization Regime}

\author{
Kirk W. Pomper ${ }^{1}$, Desmond R. Layne ${ }^{2}$, Snake C. Jones ${ }^{3}$, and \\ Michael G. Kwantes ${ }^{4}$ \\ Kentucky State University, Land Grant Program, 129 Atwood Research \\ Facility, Frankfort, KY 40601-2355
}

Additional index words. Asimina triloba, bottom heat, chlorophyll, root : shoot ratio, Kentucky banana

\begin{abstract}
Pawpaw [Asimina triloba (L.) Dunal] is a native American fruit tree that has potential as a new fruit crop or for use in landscapes, but little information is available to nurseries on the production of containerized plants. In greenhouse experiments, growth of pawpaw seedlings in Rootrainers was examined in three fertilization regimes, two root-zone temperatures, and four substrates [ProMix, 6 pine bark : 1 sand (v/v), 1 sand : 1 sphagnum peat, and 4 pine bark : 1 sand : 1 sphagnum peat medium]. A similar germination rate of $80 \%$ was obtained in all substrates. Weekly fertigation treatments were imposed when seedlings had 2 to 3 leaves, at 0,50 , and $100 \mathrm{mg} \cdot \mathrm{L}^{-1} \mathrm{~N}$ as Peters 20N-8.6P-16.6K water-soluble fertilizer plus soluble trace elements. After 140 days at the highest fertilizer rate, plant height, leaf number, and dry weight (roots, shoots, and total plant) were greater in ProMix and 1 sand :1 sphagnum peat than in 6 pine bark : 1 sand (v/v) or 4 pine bark : 1 sand : 1 sphagnum peat. Also, the root : shoot ratio was lower in ProMix and 6 pine bark : 1 sand (v/v). Overall, plant biomass production was greater in ProMix than in 6 pine bark : 1 sand $(v / v)$. In a separate experiment, bottom heat $\left(32 \pm 0.3{ }^{\circ} \mathrm{C}\right)$ hastened seedling emergence from ProMix by 9 days compared to ambient root-zone conditions $\left(24 \pm 0.2^{\circ} \mathrm{C}\right)$. An average seedling height of $10 \mathrm{~cm}$ was attained by ambient plants 79 days after sowing, whereas seedlings with bottom heat reached this height after 69 days. Seedlings subjected to bottom heat had increased leaf number $(30 \%)$, plant height $(32 \%)$, whole plant leaf area $(94 \%)$, shoot dry weight $(104 \%)$, root dry weight $(50 \%)$, lateral root dry weight $(125 \%)$, and total plant dry weight $(87 \%)$. Seedlings with bottom heat had a reduction in root : shoot ratio of $25 \%$ and in specific leaf dry weight of $16 \%$ compared to ambient plants. Seedlings subjected to bottom heat had a higher leaf chlorophyll (chl) concentration of chl a (39\%), chl b (33\%), chl p (43\%), total chl $(38 \%)$, and chl a : b ratio $(8 \%)$ than seedlings grown without bottom heat. Pawpaw seedling growth was best using ProMix with $100 \mathrm{mg} \cdot \mathrm{L}^{-1} \mathrm{~N}$ Peters applied once weekly, or using ProMix with bottom heat and $50 \mathrm{mg} \cdot \mathrm{L}^{-1} \mathrm{~N}$ Peters applied twice per week.
\end{abstract}

Pawpaw is a native American fruit tree that has potential for use as a new fruit crop or in landscapes (Darrow, 1975; Layne, 1996). Possessing a unique, almost tropical flavor, resembling a blend of banana, mango and

Received for publication: 6 Mar. 2001. Accepted for publication: 26 Aug. 2001. This research was supported by U.S. Dept. of Agriculture, Cooperative State Research, Education, and Extension Service Agreement no. KYX-10-97-28P. We thank R. Neal Peterson (founder of The PawPaw Foundation) for supplying seed used in this study. The technical assistance of E. Reed, Jr. is also gratefully acknowledged.

${ }^{1}$ Principal investigator of horticulture and curator, U.S. Dept. of Agriculture National Clonal Germplasm Repository for Asimina spp., Kentucky State Univ., and President of The PawPaw Foundation. To whom reprint requests should be addressed.

${ }^{2}$ Assistant professor of pomology and extension fruit specialist, Dept. of Horticulture, Box 340375, Clemson Univ., Clemson, S.C. 29634-0375

${ }^{3}$ Research assistant, Horticulture Program, Kentucky State Univ.

${ }^{4}$ Former research assistant, Horticulture Program, Kentucky State Univ. pineapple, pawpaw fruit have excellent fresh market and processing potential. Difficulties in nursery propagation have been a major factor in limiting development of a commercial pawpaw fruit industry. Recently, improved seedling and clonal propagation techniques for pawpaw have been demonstrated (Finneseth et al.,1998a, 1998b, 2000; Layne, 1996; Pomper et al., 2002). However, further improvements in cultural methods for the production of robust pawpaw seedlings for grafting or planting directly into orchards or landscapes would be desirable.

Pawpaw is often difficult to propagate by seed in the field. Germination rate in the field declines significantly if pawpaw seed becomes dry. Reducing seed moisture content from $37 \%$ to $25 \%$ reduces viability by $50 \%$ (Finneseth et al., 1998a). Damage to the delicate root system of field-dug pawpaw seedlings can also lead to poor seedling establishment (Layne, 1996). Due to the problems encountered by field propagation, most commercial nurseries in the United States propa- gate pawpaw trees in containers (1998 KSU Nursery Survey, unpublished). This results in a significantly greater cost to the purchaser; however, these trees usually have strong, healthy root systems at transplanting. Our long-term goal is to enhance container production of robust pawpaw seedlings that would be well suited either for grafting or for transplanting to orchards or home landscapes.

Container medium plus form and application rate of $\mathrm{N}$ can significantly affect growth of woody species (Aiello and Graves, 1997; Cruz et al., 1993; Sartain and Ingram, 1984). Because of its relatively low cost, light weight, and availability, pine bark alone or blended with sand, sphagnum peat, or perlite is a common substrate used by nurseries in the southeastern United States for container grown plants (Davidson et al., 2000; Hartmann et al., 1997). Japanese maple (Acerpalmatum Thunb.), sugar maple (Acer saccharum Marsh.), redbud (Cercis canadensis L.), flowering dogwood (Cornus florida L.), kousa dogwood (Cornus kousa), golden-rain tree (Koelreuteria paniculata Laxm.), saucer magnolia (Magnolia $\times$ soulangiana Soul.-Bod.), blackgum (Nyssa sylvatica Marsh.), and pin oak (Quercus palustris Muench.) have been grown successfully with pine bark that is supplemented with micronutrients (Wright et al., 1999). Chinese chestnut (Castanea mollissima B1.), American chestnut [C. dentata (Marsh.)], and Japanese chestnut $(C$. crenata Sieb.) seedlings have been grown successfully with a 6 pine bark : 1 sand (v/v) substrate (Huang, et al., 1994). Green ash (Fraxinus pennsylvanica Marsh.) and red oak (Quercus rubra L.) seedlings have been propagated successfully with 3 pine bark: 1 peatmoss : 1 sand $(\mathrm{v} / \mathrm{v})$ substrate (Arnold and Struve, 1989). Pawpaw seedlings have been grown successfully in containers with a 1 peat moss : 1 pine bark : 1 vermiculite (v/v) medium (Nash and Graves, 1993) and also using well-aerated growing substrate such as ProMix 'BX', which contains sphagnum peat $(75 \%$ to $85 \%$ by volume), perlite, vermiculite, macronutrients, and micronutrients (Layne, 1996). However, no studies have compared growth substrates or developed a fertilization regime for enhanced container production of pawpaw seedlings.

Elevated soil temperatures have been reported to significantly increase nutrient uptake and dry weight gain in passionfruit (Passiflora edulisf. edulis and Passiflora edulis f. flavicarpa; Menzel et al., 1994), flowering and stem length for hydroponically grown roses (Rosa xhybrida L.; Moss, 1984), and nitrogen accumulation by apple trees [Malus $\times$ sylvestris (L.) Mill. var. domestica (Borkh.) Mansf.; Toselli et al., 1999]. Hurewitz and Janes (1983) reported that tomato (Lycopersicon esculentum Mill.) leaf carbon exchange rate and leaf area increased as soil temperature was increased to $30^{\circ} \mathrm{C}$. However, root-zone temperatures $>30^{\circ} \mathrm{C}$ have been reported to restrict plant growth in some vegetable crops (Bode-Stoltzfus et al., 1998; Hurewitz and Janes, 1983; Klock et al., 1996) and several temperate tree species (Graves and Aiello, 1997; Graves et al., 1989, 1991). In 
'Rotundifolia' holly (Ilex crenata Thunb.), leaf chlorophyll levels decreased with rootzone temperatures $>30^{\circ} \mathrm{C}$ (Ruter and Ingram, 1992). Some tree species do tolerate elevated root-zone temperatures. Root-zone temperatures as high as $36{ }^{\circ} \mathrm{C}$ did not reduce whole plant dry weight production in thornless honey locust (Gleditsia triacanthos L. var. inermis Willd.) compared to $25^{\circ} \mathrm{C}$ (Klock et al., 1996). Increasing root-zone temperatures to enhance the early growth and development of container grown pawpaw seedlings has not been reported in the literature.

Therefore, the objectives of this study were: 1) to compare the effects of several media and fertilizer regimes on germination and growth of container-grown pawpaw seedlings; and 2) to determine if an increased root-zone temperature would enhance early growth and development of container-grown pawpaw seedlings in the greenhouse.

\section{Materials and Methods}

Plant material. For all experiments, pawpaw seed was harvested from open-pollinated half-sibling trees at the Western Maryland Research and Education Center in Keedysville, Md. Seed was stratified at $5{ }^{\circ} \mathrm{C}$ for 3 months and sown to a $3 \mathrm{~cm}$ depth in substrate in $5 \times 6.4$ $\times 25.4 \mathrm{~cm}\left(740 \mathrm{~cm}^{3}\right)$ containers (Rootrainers; Hummert Int., Earth City, Mo.). In all experiments, Rootrainers were watered at least weekly to runoff during germination. Seedlings were grown in a white-washed greenhouse under a 16-h photoperiod supplemented by high pressure sodium lights. Photosynthetic photon flux was measured at canopy level on a clear sunny representative day at $1200 \mathrm{HR}$ at $1200 \mu \mathrm{mol} \cdot \mathrm{m}^{-2} \cdot \mathrm{s}^{-1}$ by using a LI-COR LI-185B photometer with a quantum sensor (LI-COR, Lincoln, Nebr.).

Expt. 1, substrate study. The growth and development of pawpaw seedlings was compared in a factorial experiment in the greenhouse using three fertilizer treatments and four potting substrates: ProMix 'BX', 6 pine bark: 1 sand (v/v), 1 sand : 1 sphagnum peat, and 4 pine bark : 1 sand : 1 sphagnum peat. Fertilizer treatments were 0,50 , and $100 \mathrm{mg} \cdot \mathrm{L}^{-1} \mathrm{~N}$ as Peters (Scotts Co., Marysville, Ohio) 20N-8.6P-16.6K watersoluble fertilizer plus soluble trace elements. Experimental treatments were in a split-plot arrangement in three replicated blocks (main plot: fertilizer level, subplot: potting substrate) on three benches in the greenhouse. There were 10 replicate seedlings in each subplot. Blocks were arranged along the long, eastwest axis of the greenhouse. The greenhouse air temperature was measured every $30 \mathrm{~min}$ during the experiment using TEMP HOBO sensors (Onset Computer Corp., Pocasset, Mass.). Average greenhouse air temperatures were $29.1 \pm 0.7^{\circ} \mathrm{C}$ and $21.2 \pm 0.1^{\circ} \mathrm{C}$, at 1200 $\mathrm{HR}$ and $300 \mathrm{HR}$, respectively ( $\pm \mathrm{SE}$ ), during the experiment. In early March, stratified pawpaw seed were sown in 740-mL Rootrainers containing the substrate treatments. ProMix ' $\mathrm{BX}$ ' (Premier Horticulture, Red Hill, Penn.) was purchased, whereas the other substrates were made by combining aged, but not composted, pine bark (GSO America, Columbus, Ohio), mason sand (Quikrete All Purpose Sand, Atlanta, Ga) or sphagnum peat (Southern Importers, Greensboro, N.C.).

Substrate bulk density was determined for three replicates for each substrate after heating for $24 \mathrm{~h}$ at $50{ }^{\circ} \mathrm{C}$. Substrate $\mathrm{pH}$ was measured using $250 \mathrm{~mL}$ substrate and distilled water (1 : $1 \mathrm{v} / \mathrm{v})$. Water holding capacity for each was determined by weighing $250 \mathrm{~mL}$ of substrate in $250-\mathrm{mL}$ beakers before and after saturating the substrate and allowing it to drain from inverted beakers. Substrate analysis (Division of Regulatory Services, Univ. of Kentucky, Lexington) was performed on samples of all the substrate used in the experiment for electrical conductivity (EC), as well as $\mathrm{N}$-nitrate, $\mathrm{P}, \mathrm{K}, \mathrm{Ca}$, and $\mathrm{Mg}$ concentration. Cation exchange capacity (CEC) for each medium was determined by using an ammonia substitution method (A\&L Analytical Laboratories, Memphis, Tenn.).

Plant height and seed germination percentage were determined in each medium at the 2 to 3 leaf stage. Weekly fertilization treatments were also initiated at this time by saturating media with the appropriate liquid fertilizer. Plants were watered daily. Fertilizer treatments were prepared from a stock solution and applied by hand to the growing media; water used for preparation of the treatments had a total $\mathrm{N}$ content $\left(\mathrm{NO}_{3}\right.$ and $\left.\mathrm{NH}_{4}\right)$ of $\approx 0.7$ $\mathrm{mg} \cdot \mathrm{L}^{-1}$ and a Ca concentration of $35 \mathrm{mg} \cdot \mathrm{L}^{-1}$ (Scott Laboratories, Allentown, Pa.). The number of leaves per plant and seedling height were determined $70 \mathrm{~d}$ after imposition of fertilizer treatments, which was $140 \mathrm{~d}$ after sowing. Immediately thereafter, stems, leaves, and roots were oven-dried at $70{ }^{\circ} \mathrm{C}$ for $48 \mathrm{~h}$ and weighed.

Expt. 2, root-zone heating study. A greenhouse experiment was conducted with treatments that included two levels of root-zone temperature, ambient $\left(24 \pm 0.2^{\circ} \mathrm{C}\right)$ and bottom-heat $\left(32 \pm 0.3^{\circ} \mathrm{C}\right)$, to determine the influence of elevated soil temperature on early growth and development of container-grown pawpaw seedlings. Treatments were arranged on greenhouse benches in three replicated blocks, with 10 seedlings per treatment in each block. Seeds were sown in early September in Rootrainer cells containing ProMix. All Rootrainers were placed on sheets of Dow foam insulation $(10 \times 20 \times 2 \mathrm{~cm})$ on the bench. For the bottom-heat treatments only, the heat mat was placed directly on the foam sheet. In addition, the four sides of the Rootrainers were enclosed using the same insulation. Sides went from the bench to the top of the Rootrainer. A greenhouse temperature regime of $27 \pm 0.8^{\circ} \mathrm{C}$ day and $21 \pm 0.2^{\circ} \mathrm{C}$ night was maintained and was confirmed on a representative clear day and night. Soil temperature was elevated using ProGro propagation mats (Hummert Int., Earth City, Mo.). Average mean soil temperature was determined over a 5-d period in adjacent cells in the same zone within treatment blocks by using a soil temperature probe (Digi-Sense model 8525-00; Cole Parmer Inst. Co., Niles, Ill.) inserted to a depth of $8 \mathrm{~cm}$.
A delivery rate of $50 \mathrm{mg} \cdot \mathrm{L}^{-1} \mathrm{~N}$ as Peters $20 \mathrm{~N}-8.6 \mathrm{P}-16.6 \mathrm{~K}$ water-soluble fertilizer was applied twice weekly after seedling emergence until substrate saturation, using a Gewa proportioner (Hummert Int.). Fertilizer delivery rates were confirmed by solution analysis (Scott Laboratories, Allentown, Pa.). The fertilizer solution had a $\mathrm{pH}$ of 6.2 and $\mathrm{EC}$ was $1.56 \mathrm{dS} \cdot \mathrm{m}^{-1}$.

The number of days from sowing to seedling emergence from the substrate was evaluated. Following seedling emergence, seedlings were rogued based on size to a total of 30 seedlings per treatment. When seedlings produced three unfolded leaves, fertilization treatments began, and plant height and unfolded leaf number were measured weekly for all plants. After $114 \mathrm{~d}$, shoot and taproot length, leaf number, and total leaf area (using model CI-203 area meter; C.I.C., Vancouver, Wash.) were determined. Stems, leaves, and roots were ovendried at $70^{\circ} \mathrm{C}$ for $48 \mathrm{~h}$ and weighed.

Chlorophyll determination. Immediately prior to destructive harvest, four discs $(0.32$ $\mathrm{cm}^{2}$ each) were obtained from apical, medial and basal expanded leaves using a paper hole punch. Leaf discs were extracted for at least $24 \mathrm{~h}$ in the dark using $N, N$-dimethylformamide (Sigma, St. Louis). Extract absorbance was read at 625,647 , and $664 \mathrm{~nm}$ using a UV-VIS spectrophotometer (Beckman Instruments, Fullerton, Calif.). Chlorophyll (chl) a, b, and protochlorophyll (chl p) concentrations were determined according to the method of Moran (1982)

Statistical analysis. Data for leaves per plant, seedling height, total shoot, root, and plant dry weight, leaf area, average plant specific leaf dry weight (SLW), root : shoot ratio, chl concentration, and chl a $\mathrm{b}$ ratio in relation to treatments were subjected to GLM analysis of variance using the statistical program Costat (CoHort Software, Monterey, Calif.). Treatment means were separated based on the least significant difference (LSD) or independent $t$ tests.

\section{Results}

Expt. 1, substrate study. The container substrates differed significantly in bulk density, $\mathrm{pH}$, water retention, water holding capacity, EC, and CEC (Table 1). ProMix had the lowest density, whereas 1 sand : 1 sphagnum peat had the greatest density, almost 7 times that of ProMix. Substrate $\mathrm{pH}$ ranged from 5.1 for 6 pine bark : 1 sand (v/v) to 5.8 for 4 pine bark : 1 sand : 1 sphagnum peat. Water holding capacity of ProMix was almost 8 times greater than that of other substrates. The EC of 6 pine bark : 1 sand (v/v) was about half that of ProMix, and values for 6 pine bark : 1 sand (v/v) and 4 pine bark : 1 sand : 1 sphagnum peat were only about one-quarter that of ProMix. On a weight basis, the CEC of ProMix was $\approx 10$-fold greater than that of the other substrates. On a volume basis, the CEC of ProMix was $\approx 2$-fold greater than 1 sand : 1 sphagnum peat or 4 pine bark : 1 sand : 1 sphagnum peat, and $\approx 4$-fold greater than 6 pine bark : 1 sand (v/v). The Ca concen- 
Table 1. Properties of substrates tested for growing pawpaw seedlings in containers in the greenhouse.

\begin{tabular}{|c|c|c|c|c|c|c|c|}
\hline Media & $\begin{array}{c}\text { Density } \\
\left(\mathrm{g} \cdot \mathrm{L}^{-1}\right)\end{array}$ & $\mathrm{pH}$ & $\begin{array}{c}\text { Water } \\
\text { held } \\
\left(\mathrm{g} \mathrm{H}_{2} \mathrm{O} \cdot \mathrm{L}^{-1} \text { medium }\right)\end{array}$ & $\begin{array}{c}\text { Water holding } \\
\text { capacity } \\
(w / w \%)\end{array}$ & $\begin{array}{c}\text { Electrical } \\
\text { conductivity } \\
\left(\mathrm{dS} \cdot \mathrm{m}^{-1}\right)\end{array}$ & $\begin{array}{c}\text { Cation exchange } \\
\text { capacity } \\
\left(\mathrm{meq} \cdot 100 \mathrm{~g}^{-1}\right)\end{array}$ & $\begin{array}{c}\text { Cation exchange } \\
\text { capacity per liter } \\
\left(\mathrm{meq} \cdot \mathrm{L}^{-1}\right)\end{array}$ \\
\hline ProMix & $135.1 \mathrm{c}^{\mathrm{z}}$ & $5.57 \mathrm{ab}$ & $685 \mathrm{a}$ & $508 \pm 10$ & $1.01 \mathrm{a}$ & $195 \mathrm{a}$ & $264 \mathrm{a}$ \\
\hline Pine bark : sand $(6: 1)$ & $336.9 \mathrm{bc}$ & $5.07 \mathrm{c}$ & $203 \mathrm{~d}$ & $68 \pm 10$ & $0.58 \mathrm{~b}$ & $17 \mathrm{~b}$ & $58 \mathrm{c}$ \\
\hline Sand : sphagnum peat $(1: 1)$ & $996.8 \mathrm{a}$ & $5.31 \mathrm{bc}$ & $501 \mathrm{~b}$ & $50 \pm 1$ & $0.23 \mathrm{c}$ & $10 \mathrm{~b}$ & $103 \mathrm{~b}$ \\
\hline Pine bark : sand:sphagnum peat $(4: 1: 1)$ & $566.2 \mathrm{~b}$ & $5.80 \mathrm{a}$ & $405 \mathrm{c}$ & $72 \pm 3$ & $0.24 \mathrm{c}$ & $23 \mathrm{~b}$ & $129 \mathrm{~b}$ \\
\hline
\end{tabular}

zMean separation within columns and fertilizer level by LSD, $P<0.05 ; \mathrm{n}=3$. Mean $\pm \mathrm{SE}$

tration was $112 \pm 1,71 \pm 10,16 \pm 2,21 \pm 1$ $\mathrm{mg} \cdot \mathrm{L}^{-1}$, for ProMix, 1 sand : 1 sphagnum peat, 4 pine bark: 1 sand : 1 sphagnum peat, and 6 pine bark: 1 sand (v/v) substrates, receptively. The germination percentage was $\approx 80 \%$, and no significant differences in this rate were detected among the four media (data not shown).

Analysis of variance indicated that there was a significant interaction between the main effects of potting substrate and fertilizer regime $(P<0.001)$ for shoot and total plant dry weight, but not for root dry weight (Table 2). The $100 \mathrm{mg} \cdot \mathrm{L}^{-1} \mathrm{~N}$ fertilizer level significantly increased pawpaw seedling leaf number, height, shoot dry weight, total plant dry weight, and decreased root : shoot ratio in ProMix and 1 sand : 1 sphagnum peat (Table 2). In the $100 \mathrm{mg} \cdot \mathrm{L}^{-1} \mathrm{~N}$ fertilizer treatment, seedling total dry weight production was significantly greater in ProMix than in 1 sand : 1 sphagnum peat (independent t test, $P<0.001$; Table 2). Seedlings in 6 pine bark : 1 sand (v/ v) and 4 pine bark : 1 sand : 1 sphagnum peat stopped growing and set terminal buds $\approx 50 \mathrm{~d}$ after fertigation treatments were imposed; however, seedlings did not display chlorosis in any substrate or fertilizer treatment. Root dry weight was significantly affected by medium type and fertilizer rate, and there was no interaction between the main effects. Root dry weight was similar in ProMix (2.3 g) and 1 sand : 1 sphagnum peat $(2.1 \mathrm{~g})$, and significantly (LSD, $P<0.05$ ) greater in these media than in 6 pine bark : 1 sand $(\mathrm{v} / \mathrm{v})(1.3 \mathrm{~g})$ and 4 pine bark : 1 sand : 1 sphagnum peat $(1.6 \mathrm{~g})$. Root dry weight was similar at $50 \mathrm{mg} \cdot \mathrm{L}^{-1} \mathrm{~N}$
$(1.9 \mathrm{~g})$ and $100 \mathrm{mg} \cdot \mathrm{L}^{-1} \mathrm{~N}(2.1 \mathrm{~g})$ fertigation rates, but significantly (LSD, $P<0.05$ ) less in non-fertigated seedlings (1.6 g).

Expt. 2, root-zone heating study. Increasing the root-zone temperature from 24 to 32 ${ }^{\circ} \mathrm{C}$ by bottom heating significantly (independent t test, $P<0.001$ ) hastened seedling emergence from the soil by $9 \mathrm{~d}$. Seedlings reached the 2 to 3 leaf stage at $69 \mathrm{~d}$ after sowing with bottom-heat, but did not reach this stage in ambient plants until $79 \mathrm{~d}$ after sowing (Fig. 1A). Seedling leaf number increased steadily in both ambient and bottomheated plants until harvest (Fig. 1A). Average seedling height of $\approx 10 \mathrm{~cm}$ was not achieved by ambient plants until $79 \mathrm{~d}$ after sowing, whereas seedlings with bottom heat reached this height $69 \mathrm{~d}$ after sowing (Fig. 1B).

Bottom heat increased all growth characteristics that were measured after harvest, except root : shoot ratio (Table 3). Bottomheated seedlings had a significant increase in the following parameters relative to ambient plants: leaf number (30\%), plant height (32\%), whole plant leaf area (94\%), shoot dry weight $(104 \%)$, total root dry weight (50\%), lateral root dry weight (125\%), and total plant dry weight (87\%; Table 3). Bottom-heated seedlings showed a decrease in root : shoot ratio of $25 \%$ and in SLW of $16 \%$ compared to ambient plants. Seedlings subjected to bottom heat had an increase in leaf chl concentration for chl a (39\%), chl b (33\%), chl p $(43 \%)$, total chl $(38 \%)$, and chl a : b ratio (8\%) when compared to ambient seedlings (Table 3).

\section{Discussion}

Growth characteristics of pawpaw seedlings in 6 pine bark : 1 sand $(\mathrm{v} / \mathrm{v})$ and 4 pine bark : 1 sand : 1 sphagnum peat were poor compared to plants in ProMix or 1 sand : 1 sphagnum peat. Mandujano and Fulbright (1998) reported that pawpaw seedlings in containers grew well and appeared very healthy in the $\mathrm{pH}$ range of 5.0 to 5.6, but at $\mathrm{pH} 5.7-6.0$ they observed some leaf curling and tip burn. The $\mathrm{pH}$ range of substrate in this study was between 5.07 and 5.80 at the start of the experiment. Although the substrate $\mathrm{pH}$ may have changed during the experiment, differences in seedling growth response to the substrate used were not likely due to the differences in substrate $\mathrm{pH} .6$ pine bark : 1 sand (v/ v) and 4 pine bark: 1 sand : 1 sphagnum peat tended to dry out quickly. Even though plants were watered daily, the lower water holding capacity of the pine bark may have reduced growth of plants in 6 pine bark : 1 sand $(\mathrm{v} / \mathrm{v})$ and 4 pine bark : 1 sand : 1 sphagnum peat. Wilting of plants was not observed in 6 pine bark : 1 sand (v/v) and 4 pine bark : 1 sand : 1 sphagnum peat, but plants in these substrates stopped growing and set terminal buds about halfway through the experiment, indicating that the plants experienced stress. Plants in the pine bark substrate may also have been stressed due to reduced nutrient availability; however, all plants appeared healthy at the end of the experiment. Cation exchange capacity for substrate mixtures used in container production of plants should be reported on a volume basis, due to the light weight of some media, and

Table 2. Growth characteristics of pawpaw seedlings grown in a greenhouse with four growing substrates $70 \mathrm{~d}$ after fertilizer application and $140 \mathrm{~d}$ after sowing.

\begin{tabular}{|c|c|c|c|c|c|c|c|}
\hline Media & $\begin{array}{l}\mathrm{N} \text { as Peters } \\
\left(\mathrm{mg} \cdot \mathrm{L}^{-1}\right)\end{array}$ & $\begin{array}{l}\text { No. of } \\
\text { leaves }\end{array}$ & $\begin{array}{l}\text { Height } \\
(\mathrm{cm})\end{array}$ & $\begin{array}{l}\text { Root dry wt } \\
(\mathrm{g})\end{array}$ & $\begin{array}{l}\text { Shoot dry wt } \\
(\mathrm{g})\end{array}$ & $\begin{array}{l}\text { Total dry wt } \\
(\mathrm{g})\end{array}$ & $\begin{array}{l}\text { Root : shoot } \\
\text { ratio }\end{array}$ \\
\hline \multirow[t]{3}{*}{ ProMix } & 0 & $6.1 \mathrm{c}^{2}$ & $9.1 \mathrm{c}$ & 1.85 & $0.66 \mathrm{c}$ & $2.52 \mathrm{c}$ & $2.81 \mathrm{a}$ \\
\hline & 50 & $9.1 \mathrm{~b}$ & $13.6 \mathrm{~b}$ & 2.32 & $1.27 \mathrm{~b}$ & $3.60 \mathrm{~b}$ & $1.89 \mathrm{~b}$ \\
\hline & 100 & $11.6 \mathrm{a}$ & $17.5 \mathrm{a}$ & 2.69 & $1.91 \mathrm{a}$ & $4.60 \mathrm{a}$ & $1.46 \mathrm{c}$ \\
\hline \multirow[t]{3}{*}{ Pine bark : sand (6:1) } & 0 & $5.4 \mathrm{a}$ & $6.6 \mathrm{a}$ & 1.26 & $0.50 \mathrm{a}$ & $1.76 \mathrm{a}$ & $2.59 \mathrm{~b}$ \\
\hline & 50 & $5.1 \mathrm{a}$ & $6.2 \mathrm{a}$ & 1.33 & $0.52 \mathrm{a}$ & $1.86 \mathrm{a}$ & $2.94 \mathrm{ab}$ \\
\hline & 100 & $5.2 \mathrm{a}$ & $6.2 \mathrm{a}$ & 1.44 & $0.45 \mathrm{a}$ & $1.90 \mathrm{a}$ & $3.29 \mathrm{a}$ \\
\hline \multirow[t]{3}{*}{ Sand : sphagnum peat $(1: 1)$} & 0 & $6.1 \mathrm{c}$ & $8.7 \mathrm{~b}$ & 1.81 & $0.70 \mathrm{c}$ & $2.51 \mathrm{c}$ & $2.65 \mathrm{a}$ \\
\hline & 50 & $7.2 \mathrm{~b}$ & $10.1 \mathrm{a}$ & 2.16 & $0.90 \mathrm{~b}$ & $3.07 \mathrm{~b}$ & $2.65 \mathrm{a}$ \\
\hline & 100 & $10.8 \mathrm{a}$ & $14.5 \mathrm{a}$ & 2.43 & $1.46 \mathrm{a}$ & $3.88 \mathrm{a}$ & $1.71 \mathrm{~b}$ \\
\hline \multirow{3}{*}{$\begin{array}{l}\text { Pine bark : sand : sphagnum peat } \\
\quad(4: 1: 1)\end{array}$} & 0 & $5.0 \mathrm{~b}$ & $6.5 \mathrm{~b}$ & 1.42 & $0.46 \mathrm{~b}$ & $1.88 \mathrm{~b}$ & $3.19 \mathrm{a}$ \\
\hline & 50 & $5.2 \mathrm{~b}$ & $7.5 \mathrm{a}$ & 1.71 & $0.55 \mathrm{ab}$ & $2.27 \mathrm{a}$ & $3.21 \mathrm{a}$ \\
\hline & 100 & $5.9 \mathrm{a}$ & $7.6 \mathrm{a}$ & 1.80 & $0.63 \mathrm{a}$ & $2.43 \mathrm{a}$ & $2.96 \mathrm{a}$ \\
\hline \multicolumn{8}{|l|}{ Significance } \\
\hline Fertilizer & & *** & ** & *** & $* *$ & *** & $*$ \\
\hline Media & & $* * *$ & *** & $* * *$ & $* * *$ & $* * *$ & $* * *$ \\
\hline Fertilizer $\times$ media & & *** & $* * *$ & NS & $* * *$ & $* * *$ & $* * *$ \\
\hline
\end{tabular}

${ }^{\mathrm{z}}$ Mean separation within substrate and fertilizer level by LSD, $P<0.05$.

Ns, $, * *, * * *$ Nonsignificant or significant at $P<0.01,0.001$, and 0.0001 , respectively. 


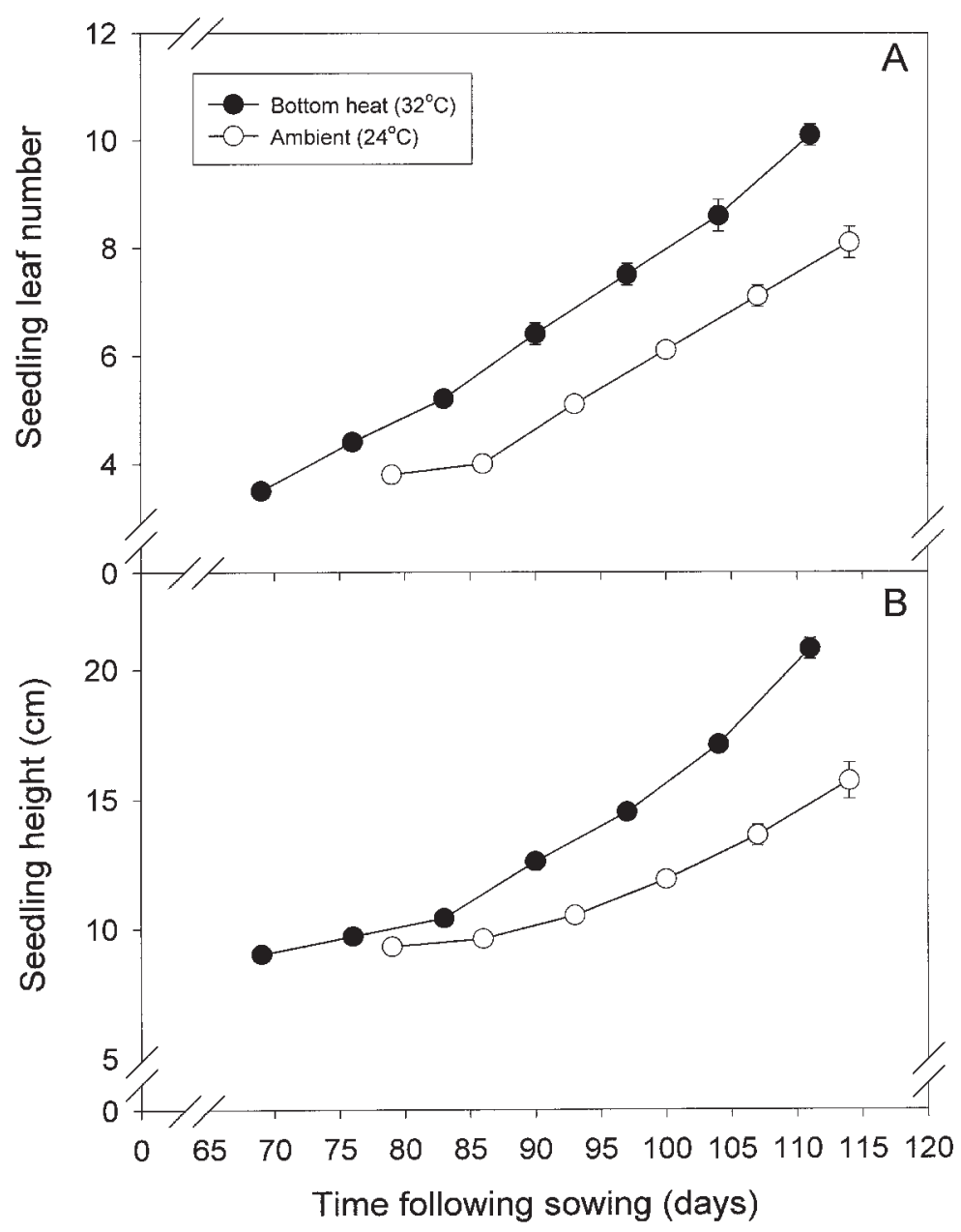

Fig. 1. Response of pawpaw [Asimina triloba (L.) Dunal] seedlings to an ambient root-zone temperature at $24{ }^{\circ} \mathrm{C}(\bigcirc)$ and bottom heating at $32{ }^{\circ} \mathrm{C}(\bullet)$ for seedling leaf number for (A) fully expanded leaves and (B) height after seedlings had emerged from the growing stubstrate. Mean $\pm \mathrm{sE}, \mathrm{n}=3$. because the amount of soil is determined by the volume of the container. On a volume basis, CEC of ProMix was greater than other media. Interestingly, the CEC values of 1 sand : 1 sphagnum peat and 4 pine bark : 1 sand : 1 sphagnum peat substrate were similar, suggesting that the lower water holding capacity of 4 pine bark : 1 sand : 1 sphagnum peat resulted in the reduced seedling growth in this substrate. With daily watering, it is also likely that the nutrients (applied weekly) were leached more rapidly from the 6 pine bark : 1 sand (v/ v), 1 sand : 1 sphagnum peat, and 4 pine bark : 1 sand : 1 sphagnum peat substrate, resulting in greater plant growth in ProMix. As the pine bark decomposed in containers during the experiment, some applied nutrients may have been used by microorganisms. If seedlings in 6 pine bark : 1 sand (v/v) and 4 pine bark : 1 sand : 1 sphagnum peat were irrigated and fertilized more frequently, growth of seedlings in these substrates might have been en-
Table 3. Influence of bottom heating on growth characteristics and leaf chlorophyll (Chl) concentration on greenhouse grown pawpaw seedlings 114 days after sowing.

\begin{tabular}{lccc}
\hline \hline & $\begin{array}{c}\text { Ambient } \\
\left(24{ }^{\circ} \mathrm{C}\right)\end{array}$ & $\begin{array}{c}\text { Bottom heat } \\
\left(32{ }^{\circ} \mathrm{C} \text { at } 8 \mathrm{~cm} \text { depth }\right)\end{array}$ & $\begin{array}{c}\text { Independent } t \text { test } \\
P \text { value }\end{array}$ \\
\hline Leaf number & 9.4 & 12.3 & $<0.001$ \\
Plant height $(\mathrm{cm})$ & 15.7 & 20.8 & $<0.002$ \\
Whole plant leaf area $\left(\mathrm{cm}^{2}\right)$ & 305 & 593 & $<0.001$ \\
Specific leaf dry weight $\left(\mathrm{SLW} ; \mathrm{g} \cdot \mathrm{m}^{-2}\right)$ & 0.24 & 0.20 & $<0.001$ \\
Shoot dry weight $(\mathrm{g})$ & 1.10 & 2.25 & $<0.001$ \\
Total root dry weight $(\mathrm{g})$ & 0.48 & 0.72 & $<0.001$ \\
Lateral root dry weight $(\mathrm{g})$ & 0.12 & 0.27 & $<0.001$ \\
Total plant dry weight $(\mathrm{g})$ & 1.58 & 2.97 & $<0.001$ \\
Root:shoot ratio & 0.43 & 0.32 & $<0.001$ \\
Chl a $\left(\mathrm{g} \cdot \mathrm{m}^{-2}\right)$ & 41.5 & 57.9 & $<0.001$ \\
Chl b $\left(\mathrm{g} \cdot \mathrm{m}^{-2}\right)$ & 11.6 & 15.5 & $<0.001$ \\
Chl p $\left(\mathrm{g} \cdot \mathrm{m}^{-2}\right)$ & 1.6 & 2.3 & $<0.001$ \\
Total chl $\left(\mathrm{g} \cdot \mathrm{m}^{-2}\right)$ & 53.1 & 73.4 & $<0.001$ \\
Chl a:b ratio & 3.5 & 3.8 & \\
\hline
\end{tabular}

hanced. However, extra labor required for the additional watering would not make these substrates attractive to small nurseries that do not have automated watering systems. A substrate that contains less pine bark and more sphagnum peat might also serve as a successful container substrate for production of pawpaw seedlings. ProMix contains dolomitic and calcitic limestone, and $\mathrm{Ca}$ concentration was almost 2-fold greater for ProMix than 1 sand : 1 sphagnum peat, and $\approx 5$-fold greater in 4 pine bark : 1 sand : 1 sphagnum peat, and 6 pine bark : 1 sand $(\mathrm{v} / \mathrm{v})$ substrates. The irrigation water used in this study contained $\mathrm{Ca}$ at 35 $\mathrm{mg} \cdot \mathrm{L}^{-1}$. It is possible that low Ca substrate levels may have limited plant growth in the 4 pine bark: 1 sand: 1 sphagnum peat, and 6 pine bark : 1 sand (v/v) substrates; however, Ca deficiency symptoms were not observed with plants on these substrates. Overall, ProMix with a once weekly application of $100 \mathrm{mg} \cdot \mathrm{L}^{-1}$ $\mathrm{N}$ as Peters water-soluble fertilizer served as an excellent substrate for the production of robust pawpaw seedlings for transplanting. Seedlings in the 1 sand : 1 sphagnum peat substrate preformed well, but the heavy weight of this medium would also make containers heavy and more cumbersome to handle.

Pawpaw seedlings responded very favorably to root-zone warming to $32{ }^{\circ} \mathrm{C}$ by increasing shoot, root, and total dry matter production. Seedling emergence from the substrate $9 \mathrm{~d}$ before their ambient substrate temperature counterparts gave seedlings with bottom heat a significant advantage in their development. The positive response of seedlings to bottom heat indicates that pawpaw is similar to other tree species, such as thornless honey locust (Klock et al., 1996), that tolerate elevated root-zone temperatures. Further research will be required to determine the optimum soil temperature for pawpaw seedling growth and development.

Elevated soil temperatures have been reported to significantly increase nutrient uptake and dry weight production in passionfruit (Menzel et al., 1994), and they have increased bloom yield and stem length for hydroponically grown roses (Moss, 1984). Elevated soil temperatures significantly increased nutrient uptake and dry weight gain in passionfruit (Menzel et al., 1994) and $\mathrm{N}$ accumulation by apple trees (Toselli et al., 1999). LopezCantarero et al. (1994) reported that leaf chl levels were directly related to $\mathrm{N}$ and $\mathrm{P}$ fertilization levels in Solanum melongena L. Based on the significantly higher leaf chlorophyll levels, whole plant leaf area, and biomass accumulated for bottom-heated vs. ambient seedlings, it is likely that seedlings with bottom heat had a higher nutrient uptake and quantity and greater photosynthetic activity. The Peters $20 \mathrm{~N}-8.6 \mathrm{P}-16.6 \mathrm{~K}$ plus soluble trace elements used in this study contained $3.94 \%$ $\mathrm{NH}_{4}-\mathrm{N}, 6.05 \% \mathrm{NO}_{3}-\mathrm{N}$, and $10.01 \%$ urea-N; we did not include any other fertilizer formulations as treatments; therefore it is unclear if pawpaw prefers to utilize one $\mathrm{N}$ form over another.

The shoot, root, and total dry weight of pawpaw seedlings in the bottom heat study 
were less than in plants grown in ProMix in the media study. Fertilization regimes were slightly different. Plants in the substrate study received a weekly application of 100 $\mathrm{mg} \cdot \mathrm{L}^{-1} \mathrm{~N}$, whereas plants in the bottom heat study received twice weekly applications of $50 \mathrm{mg} \cdot \mathrm{L}^{-1} \mathrm{~N}$ fertilizer. Also, warmer ambient greenhouse temperatures, $29.1 \pm 0.7^{\circ} \mathrm{C}$ day and $21.2 \pm 0.1{ }^{\circ} \mathrm{C}$ night, during the media experiment likely resulted in the greater growth of pawpaw seedling compared to those, $27 \pm$ $0.8^{\circ} \mathrm{C}$ day and $21 \pm 0.2^{\circ} \mathrm{C}$ night in the bottom heat experiment. Plants in the substrate experiment were subjected to warmer daytime temperatures, but lower temperatures at night. It is possible that there were higher losses of carbon during the night in bottom-heated plants compared to plants in the media experiment, due to increased nighttime respiration with bottom heat.

Hurewitz and Janes (1983) noted that tomato leaf carbon exchange rate and leaf area increased as soil temperature increased to $30{ }^{\circ} \mathrm{C}$. They hypothesized that increased plant growth at warmer soil temperatures may have been due to the effect of increased root sink activity on leaf photosynthetic rate. Other factors that may have contributed to the growth enhancement noted for bottom-heated seedlings included changes in water use efficiency and production or availability of root-derived cytokinins. Also, with such heating there are potential decreases in both the time to produce a saleable plant and the cost of heating greenhouses (Vogelezang, 1991). Bottom-heated seedlings also produced greater lateral and total root dry weight than ambient seedlings, which could result in a higher rate of establishment of bottom-heated seedlings in the field.

In conclusion, ProMix with a once weekly application of $100 \mathrm{mg} \cdot \mathrm{L}^{-1} \mathrm{~N}$ as Peters watersoluble fertilizer served as an excellent substrate for the production of robust pawpaw seedlings for transplanting into the field or into larger containers. Pawpaw seedlings responded very favorably to root-zone warming to $32^{\circ} \mathrm{C}$, by speeding seedling emergence, and increasing shoot, root, and total dry matter production in developing seedlings.

\section{Literature Cited}

Aiello, A.S. and W.R. Graves. 1997. Container medium and nitrogen form affect production of Amur Maackia (Maackia amurensis Rupr. \&
Maxim.). HortScience 32:1200-1203.

Arnold, M.A. and D.K. Struve. 1989. Growing green ash and red oak in $\mathrm{CuCO}_{3}$-treated containers increase root regeneration and shoot growth following transplant. J. Amer. Soc. Hort. Sci. 114:402-406.

Bode-Stoltzfus, R.M., H. G. Taber, and A.S. Aiello. 1998. Effect of increasing root-zone temperature on growth and nutrient uptake by 'Gold Star' muskmelon plants. J. Plant Nutr. 21:321328

Cruz, C., S.H. Lips, and M.A. Martins-Loucao. 1993. Growth and nutrition of carob plants as affected by nitrogen sources. J. Plant Nutr. 16:115.

Darrow, G.M. 1975. Minor temperate fruits, p. 276277. In: J. Janick and J.N. Moore (eds.) Advances in fruit breeding. Purdue Univ. Press, West Lafayette, Ind.

Davidson, H., R. Mecklenberg, C. Peterson. 2000. Nursery Management, Administration and Culture. Prentice Hall. Upper Saddle River, N.J.

Finneseth, C.L.H., D.R. Layne, and R.L. Geneve. 1998a. Morphological development of pawpaw [Asimina triloba $(\mathrm{L}$.$) Dunal] during seed germi-$ nation and seedling emergence. HortScience 33:802-805.

Finneseth, C.L.H., D.R. Layne, and R.L. Geneve. 1998b. Requirements for seed germination in North American pawpaw [Asimina triloba (L.) Dunal]. Seed Sci. Technol. 26:471-480.

Finneseth, C.L.H., D.R. Layne, and R.L. Geneve. 2000. Establishment of North American pawpaw [Asimina triloba $(\mathrm{L}$.) Dunal] shoots in vitro from mature and juvenile explants. Acta Hort. 520:97-102.

Graves, W.R., R.J. Joly, and M.N. Dana. 1989. Root-zone temperature affects water status and growth of red maple. J. Amer. Soc. Hort. Sci. 114:406-410.

Graves, W.R., R.J. Joly, and M.N. Dana. 1991. Water use and growth of honey locust and treeof-heaven at high root-zone temperature. HortScience 26:1309-1312.

Graves, W.R. and A.S. Aiello. 1997. High root-zone temperature causes similar changes in water relations and growth of silver maples from 33 degrees and 44 degrees N latitude. J. Amer. Soc. Hort. Sci. 122:195-199.

Hartmann, H.T., D.E. Kester, F.T. Davies, Jr., and R.L. Geneve. 1997. Plant propagation, principles and practices. Prentice Hall. Upper Saddle River, N.J.

Huang, H., J.D. Norton, G.E. Boyan, and B.R. Abrahams. 1994. Graft compatibility among Chestnut (Castanea) species. J. Amer. Soc. Hort. Sci. 119:1127-1132.

Hurewitz, J. and H.W. Janes. 1983. Effect of altering the root-zone temperature on growth, translocation, carbon exchange rate, and leaf starch accumulation in the tomato. Plant Physiol. 73:46-50.
Klock, K.A., W.R. Graves, and H.G. Taber. 1996. Growth and phosphorus, zinc, and manganese content of tomato, muskmelon, and honey locust at high root-zone temperatures. J. Plant Nutr. 19:795-806.

Layne, D.R. 1996. The pawpaw [Asimina triloba (L.) Dunal]: A new fruit crop for Kentucky and the United States. HortScience 31:777-784.

Lopez-Cantarero, I., F.A. Lorente, and L. Romero. 1994. Are chlorophylls good indicators of nitrogen and phosphorus levels? J. Plant Nutr. 17:979990.

Mandujano, M. and D.W. Fulbright. 1998. Meristem dieback of greenhouse-grown pawpaw is associated with soil $\mathrm{pH}$. Annu. Rpt. Northern Nut Growers 89:103-107.

Menzel, D.M., D.W. Turner, V.J. Doogan, and D.R. Simpson. 1994. Root shoot interactions in passionfruit (Passiflora sp.) under the influence of changing root volumes and soil temperatures. J. Hort. Sci. 69:552-564.

Moran, R. 1982. Formulae for the determination of chlorophyllous pigments extracted with $N, N$ dimethylformamide. Plant Physiol. 69:13761381.

Moss, G.I. 1984. The effects of root-zone warming on the yield and quality of roses grown in a hydroponic system. J. Hort. Sci. 59:549-558.

Nash, L.J. and W.R. Graves. 1993. Drought and flood stress effects on plant development and leaf water relations of five taxa of trees native to bottomland habitats. J. Amer. Soc. Hort. Sci. 118:845-850.

Pomper, K.W., D.R. Lane, and S.C. Jones. 2002. Incident irradiance and cupric hydroxide container treatment effects on early growth and development of container-grown pawpaw seedlings. J. Amr. Soc. Hort. Sci. 127:13-19.

Ruter, J.M. and D.L. Ingram. 1992. High root-zone temperatures influence RuBisCO activity and pigment accumulation in leaves of 'Rotundifolia' holly. J. Amer. Soc. Hort. Sci. 117:154-157.

Sartain, J.B. and D.L. Ingram. 1984. Influence of container medium, lime, and nitrogen source on growth of woody ornamentals. J. Amer. Soc. Hort. Sci. 109:882-886.

Toselli, M., J.A. Flore, B. Marangoni, and A. Masia. 1999. Effects of root-zone temperature on nitrogen accumulation by non-bearing apple trees. J. Hort. Sci. Biotechnol. 74:118-124.

Vogelezang, J.V.M. 1991. Effect of root-zone and air temperature on growth, ornamental value and keepability of Ficus benjamina and Scheffler arboricola 'Compacta'. Sci. Hort. 46:301-313.

Wright, A.N., A.X. Niemiera, J.R. Harris, and R.D. Wright. 1999. Preplant lime and micronutrient amendments to pine bark affect growth of seedlings of nine container-grown tree species. HortScience 34:669-673. 